\title{
ASSESSMENT OF HAEMOGLOBIN RESPONSE TO INTRAVENOUS IRON THERAPY IN NON-DIALYTIC CHRONIC KIDNEY DISEASE PATIENTS WITH ANAEMIA
}

\author{
Murugesan $V^{1}$, Shanmugasundaram $A^{2}$ \\ ${ }_{1}^{1}$ Assistant Professor, Department of Nephrology, Government Kilpauk Medical College, Chennai, Tamilnadu, India. \\ ${ }^{2}$ Assistant Professor, Department of Nephrology, Government Royapettah Hospital, Government Kilpauk Medical College, Chennai, \\ Tamilnadu, India.
}

\section{ABSTRACT}

\section{BACKGROUND}

There is difficulty in assessing iron status in Chronic Kidney Disease (CKD) patients with anaemia, because of functional iron deficiency.

The aim of the study was to assess Haemoglobin (Hb) response to Intravenous (IV) iron therapy in CKD patients with anaemia and correlate $\mathrm{Hb}$ response with available iron indices.

\section{MATERIALS AND METHODS}

The study is a clinical, prospective, observational study. Forty newly detected CKD patients with GFR $<30 \mathrm{~mL} / \mathrm{min} / 1.73 \mathrm{~m}{ }^{2} \mathrm{and} \mathrm{Hb}$ $<10 \mathrm{~g} / \mathrm{dL}$ were included in the study. Ten daily doses of $100 \mathrm{mg}$ Intravenous (IV) iron sucrose injections were administered without erythropoietin when Transferrin Saturation (TSAT) was $<30 \%$ irrespective of serum ferritin levels. Their Hb and iron indices responses were assessed one month after the last dose of IV iron. The sample size required was taken for convenience.

\section{RESULTS}

There was a $0.8 \mathrm{~g} / \mathrm{dL} \mathrm{Hb}$ increase. Hb response was more when TSAT was less than $20 \%$. There was Hb response even if serum ferritin was more than $500 \mathrm{ng} / \mathrm{mL}$, when TSAT was less than $20 \%$ and when TSAT was $21-30 \%$ moderate. Hb response was present if serum ferritin was $<500 \mathrm{ng} / \mathrm{mL}$ and no $\mathrm{Hb}$ response if serum ferritin was $>500 \mathrm{ng} / \mathrm{mL}$.

\section{CONCLUSION}

TSAT $<20 \%$ is a better predictor of $\mathrm{Hb}$ response in non-dialytic CKD patients with anaemia. Treatment with $1 \mathrm{~g}$ IV iron sucrose is beneficial in non-dialytic CKD patients with anaemia in spite of high serum ferritin levels when TSAT is $<20 \%$. Further studies are needed in this regard.

\section{KEY WORDS}

Anaemia, CKD, Haemoglobin Response, Ferritin, TSAT.

HOW TO CITE THIS ARTICLE: Murugesan V, Shanmugasundaram A. Assessment of haemoglobin response to intravenous iron therapy in non-dialytic chronic kidney disease patients with anaemia. J. Evolution Med. Dent. Sci. 2018;7(43):4621-4624, DOI: $10.14260 /$ jemds/2018/1031

\section{BACKGROUND}

Anaemia is said to be uncommon in CKD stages 1 - 3 patients (GFR > $30 \mathrm{~mL} / \mathrm{min} / 1.73 \mathrm{~m} 2$ ), except in diabetic patients where $\mathrm{Hb}$ begins to fall even when GFR is $45 \mathrm{~mL} / \mathrm{min} / 1.73$ m2.(1) In India $\mathrm{Hb}$ levels $<11 \mathrm{~g} / \mathrm{dL}$ are $66.8 \%, 75 \%$ and $94.7 \%$ in stages 3, 4, 5 CKD patients respectively.(2) Survey in predialysis patients in Europe revealed that only 32\% CKD had $\mathrm{Hb}$ above $11 \mathrm{~g} / \mathrm{dL}$.(3) Treatment of anaemia early slows the progression of CKD.(4) Anaemia increases cardiovascular morbidity and mortality.(5) So evaluation and treatment of anaemia is important in pre-dialytic CKD patients. Erythropoietin deficiency, iron deficiency, deficiencies of vitamins B6, folic acid and B12, chronic inflammation and infections, marrow fibrosis due to uraemia and hepcidin excess are the causes of anaemia in CKD patients.(6) According to KDIGO guidelines, non-dialytic CKD patients with anaemia

'Financial or Other Competing Interest': None.

Submission 28-05-2018, Peer Review 05-10-2018,

Acceptance 11-10-2018, Published 22-10-2018.

Corresponding Author:

Dr. Shanmugasundaram $A$,

Department of Nephrology,

Government Royapettah Hospital,

Government Kilpauk Medical College,

Kilpauk, Chennai-600010, Tamilnadu, India.

E-mail: sddrshan@gmail.com

DOI: $10.14260 /$ jemds/2018/1031 should be given 3 months trial of oral iron or IV iron when serum ferritin level is $<500 \mathrm{ng} / \mathrm{mL}$ and TSAT is $<30 \%$. ${ }^{(7)}$ KHA-CARI guidelines prefer IV Iron in stage 1 - 3 CKD. ${ }^{(8)}$ Shankar $\mathrm{P}$ Nagaraju demonstrated equal TSAT response between oral vs. IV Iron therapy and higher ferritin response with IV Iron group.(9) In dialytic CKD patients with anaemia, TSAT is a better predictor of Hb response and TSAT $<34 \%$ predicts the $\mathrm{Hb}$ response better.(10) Here, an attempt is made to find better predictor of $\mathrm{Hb}$ response in non-dialytic CKD patients.

\section{MATERIALS AND METHODS}

The study is a clinical, prospective and observational study which is conducted at Govt. Kilpauk Medical College Hospital, Chennai. Forty newly detected CKD patients with GFR $<30$ $\mathrm{mL} / \mathrm{min} / 1.73 \mathrm{~m}^{2}$ and $\mathrm{Hb}<10 \mathrm{~g} / \mathrm{dL}$ were included in the study. Nearly, 15 - 20 new CKD stages 4 and 5 patients attend our Nephrology OPD. One hundred patients were tested for $\mathrm{Hb}$ levels over a period of 6 months, of which $80 \%$ had $\mathrm{Hb}$ levels $<10 \mathrm{~g} / \mathrm{dL}$. After excluding patients with active infections/ active bleeding, recent myocardial infarction, congestive cardiac failure, on maintenance haemodialysis, already on iron or erythropoietin therapy sixty willing patients were tested for serum ferritin, serum iron, total Iron Binding Capacity (TIBC) and TSAT (calculated). To assess haemoglobin (Hb) response to intravenous (IV) iron therapy in CKD patients with anaemia and correlate $\mathrm{Hb}$ response with 
available iron indices. Twelve patients had TSAT $>30 \%$. Finally, 48 patients were given 10 daily doses of $100 \mathrm{mg}$ Iron sucrose infusion without erythropoietin. $\mathrm{Hb}$ response and Iron indices were analysed after 1 month. The sample size required was taken for convenience.

\section{Sampling Technique}

Convenient sampling method.

Quantitative determination of serum iron was done by colorimetric principle using ferrozine (spinreact), TIBC by saturation - precipitation with magnesium carbonate and serum ferritin by enzyme immunoassay using pathozyme ferritin (omega diagnostics).

TSAT is calculated by formula TSAT $=\underline{\text { Serum Iron } \times 100}$ TIBC

\section{Statistical Analysis}

For statistical analysis one-way ANOVA was used. This is an extension of the Wilcoxon Rank-Sum Test, used to compare population location parameters (mean, median etc.) among two or more groups including independent samples. It is based on the ranks of the data and for non-normal data were reported as median (Interquartile Range [IQR]). Means of 2 continuous normally distributed variables were compared by independent samples. Student's t-test and Mann-Whitney U test were used respectively to compare means of 2 and 3 or more groups of variables not normally distributed. Analysis of the data was done using a software SPSS system 16.0.
Microsoft Word and Excel had been used to generate graphs and tables.

\section{RESULTS}

The mean age was 55.82 years. Mean GFR was 13.3 $\mathrm{mL} / \mathrm{min} / 1.73 \mathrm{~m}^{2}$ and mean pre-treatment $\mathrm{Hb}$ was $7.45 \mathrm{~g} / \mathrm{dL}$. There was a mean $0.8 \mathrm{~g} / \mathrm{dL}$ increase in $\mathrm{Hb}$ post treatment.

\begin{tabular}{|c|c|c|c|}
\hline 1 & $\begin{array}{c}\text { Total number of stage } 4 \text { and } 5 \text { CKD } \\
\text { patients }\end{array}$ & \multicolumn{2}{|c|}{100} \\
\hline 2. & Patients with $\mathrm{Hb}<10 \mathrm{~g} / \mathrm{dL}$ & \multicolumn{2}{|c|}{80} \\
\hline 3. & $\begin{array}{l}\text { Unwilling and meeting exclusion } \\
\text { criteria patients }\end{array}$ & \multicolumn{2}{|c|}{$\begin{array}{c}20+12 \\
(\text { TSAT }>30 \%)\end{array}$} \\
\hline 4. & $\begin{array}{l}\text { Willing patients initially attended } \\
\text { study }\end{array}$ & \multicolumn{2}{|c|}{48} \\
\hline 5. & Withdrawal due to allergic reactions & \multicolumn{2}{|c|}{2} \\
\hline 6. & Withdrawal due to personal reasons & \multicolumn{2}{|c|}{2} \\
\hline 7. & Missed follow-up & \multicolumn{2}{|c|}{4} \\
\hline 8. & Final study population & Median & IQR \\
\hline & 40 & 48.2 & 86 \\
\hline
\end{tabular}

If we take $\mathrm{Hb}$ increase $>1 \mathrm{~g} / \mathrm{dL}$ as adequate, 19 patients (47.5\%) had adequate $\mathrm{Hb}$ response. Nearly, $45.8 \%$ of males and $50 \%$ of females had adequate $\mathrm{Hb}$ response. Nearly, $75 \%$ of age group $<40$ years, $29 \%$ of age group of $41-50 \%, 41 \%$ of age group 51 - 60 years and $35 \%$ of age > 61 years had adequate $\mathrm{Hb}$ response. One had $3 \mathrm{~g} / \mathrm{dL}$ Hb increase, 18 had 1$2 \mathrm{~g} / \mathrm{dL} \mathrm{Hb}$ response, 13 patients had $<1 \mathrm{~g} / \mathrm{dL}$ Hb increase and 8 patients had reduced post treatment $\mathrm{Hb}$.

\begin{tabular}{|c|c|c|c|c|}
\hline Iron Indices & & Pre-Treatment Levels & Post-Treatment Levels & P value \\
\hline \multirow{4}{*}{ Serum Ferritin } & Mean & 213 & 236.6 & \multirow{4}{*}{$\begin{array}{l}0.05 \text { (Wilcoxon signed- } \\
\text { rank test) }\end{array}$} \\
\hline & Median & 233.55 & 318.4 & \\
\hline & IQR & 343.05 & 270.25 & \\
\hline & Standard Deviation & 217.2801 & 172.4157 & \\
\hline \multirow{4}{*}{ TSAT $\%$} & Mean & 21.3 & 25.9 & \multirow{4}{*}{0.000} \\
\hline & Median & 25.1 & 29 & \\
\hline & IQR & 6.5 & 14.58 & \\
\hline & Standard Deviation & 5.2734 & 9.30805 & \\
\hline \multicolumn{5}{|c|}{ Table 2. Shows Individual Iron Indices Responses } \\
\hline
\end{tabular}

Since pre-test and post-test ferritin levels are not normally distributed, non-parametric t-test using Wilcoxon signed-rank test was done which shows statistical significance.

\begin{tabular}{|c|c|c|c|c|c|c|}
\hline Ferritin Groups & Pre-Treatment Serum Ferritin & No. of Patients & Hb Response(g/dL) & Standard Deviation & F & P value \\
\hline 1. & $<200 \mathrm{ng} / \mathrm{mL}$ & 17 & 1.1 & .74117 & \\
\\
\hline 2. & $200-500 \mathrm{ng} / \mathrm{mL}$ & 15 & 0.74 & .86373 & 4.248 & 0.022 \\
\hline 3. & $>500 \mathrm{ng} / \mathrm{mL}$ & 8 & 0.16 & .53436 & \\
\hline \multicolumn{5}{|c|}{ Table 3 } \\
\hline
\end{tabular}

\begin{tabular}{|c|c|c|c|c|c|c|}
\hline TSAT Groups & Pre-Treatment TSAT & No. of Patients & Hb Response (g/dL) & Standard Deviation & F & P value \\
\hline 1. & $<20 \%$ & 7 & 1.34 & .30472 & 4.34 \\
\hline 2. & $20-30 \%$ & 33 & 0.66 & .84549 & 0.044 \\
\hline \multicolumn{7}{|c|}{ Table 4 } \\
\hline
\end{tabular}

\section{DISCUSSION}

Anaemia is diagnosed when $\mathrm{Hb}$ level is below $13 \mathrm{~g} / \mathrm{dL}$ in men and below $12 \mathrm{~g} / \mathrm{dL}$ in women.(7) In CKD patients, the desirable $\mathrm{Hb}$ is around $11 \mathrm{~g} / \mathrm{dL}$. Assessment of iron status in CKD patients with anaemia is difficult. TSAT and serum ferritin are favoured markers for assessment of iron status because of their widespread availability, extensive literature base and familiarity. Ferritin is an acute phase reactant and has gender differences. Serum iron levels may be modified by diurnal variation and food intake. TSAT is also an acute phase reactant and may be falsely high in malnutrition and falsely low in inflammation. Serum ferritin $>250 \mathrm{ng} / \mathrm{mL}$ is associated with higher mortality in non-dialytic CKD patients. Lower TSAT $<17$ is associated with higher mortality and 
higher TSAT is associated with low mortality and higher chances of progression to ESRD.(11)

There is only one patient (2.5\%) with absolute iron deficiency (serum ferritin $<100 \mathrm{ng} / \mathrm{mL}$ and TSAT $<20 \%$ ) in our study. 4 patients (10\%) have serum ferritin level less than $100 \mathrm{ng} / \mathrm{mL}$ and seven patients (17.5\%) have TSAT $<20 \%$. According to NHANES III absolute iron deficiency was present in $57.8 \%$ to $58.8 \%$ of men and $69.9 \%$ to $72.8 \%$ of women.(12) Of the 102 patients from New York, 28.4\% had absolute iron deficiency and $54.9 \%$ had TSAT $<20 \%$ and $41.2 \%$ had ferritin $<100 \mathrm{ng} / \mathrm{mL} .{ }^{(13)}$

There is $0.8 \mathrm{~g} / \mathrm{dL}$ increase in $\mathrm{Hb}$ level one month after 1 gram of IV Inj. Iron sucrose. In a similar study, Vikrant observed $1.6 \mathrm{~g} / \mathrm{dL} \mathrm{Hb}$ response in 450 non-dialytic patients in northern India.(14) In similar studies, Agarwal has observed $0.4 \mathrm{~g} / \mathrm{dL}$ Hb response in 75 patients.(15) Qunibi observed 1.16 $\mathrm{g} / \mathrm{dL} \mathrm{Hb}$ response in 188 patients,(16) Spinowitz $0.62 \mathrm{~g} / \mathrm{dL}$ in 188 patients,(17) Van Wyck $0.7 \mathrm{~g} / \mathrm{dL}$ in 188 patients,(18) Gotloib $1.8 \mathrm{~g} / \mathrm{dL}$ in 47 patients.(19) Gabriel Mircescu observed $1.6 \mathrm{~g} / \mathrm{dL}$ response in 160 Romanian patients. ${ }^{(20)}$

Nearly, $2.5 \%$ had $>2 \mathrm{~g} / \mathrm{dL}$ Hb response, $45 \%$ had $1-2$ $\mathrm{g} / \mathrm{dL}$ response, $32.5 \%$ had $<1 \mathrm{~g} / \mathrm{dL} \mathrm{Hb}$ response and $20 \%$ had negative response in our study. In a similar study, Gotloib observed $>2 \mathrm{~g} / \mathrm{dL}$ response in $48.9 \%, 1-2 \mathrm{~g} / \mathrm{dL}$ in $19.1 \%$ and $<1 \mathrm{~g} / \mathrm{dL}$ in $21.3 \%$.(19) In our study, $47.5 \%$ had adequate $\mathrm{Hb}(>1 \mathrm{~g} / \mathrm{dL})$ response. Vikrant observed that $72 \%$ had adequate $\mathrm{Hb}$ response.(14)

\section{Drive Study}

Dialysis patients' response to IV Iron with Elevated Ferritin (DRIVE) Study, a controlled, multicenter (37 centers) USA trial in which 134 haemodialysis patients were compared with $1 \mathrm{~g}$ of ferric gluconate therapy ( 68 patients) and no iron therapy ( 66 patients) if $\mathrm{Hb}$ is $<11 \mathrm{~g} / \mathrm{dl}$, serum ferritin of 500 to $1200 \mathrm{ng} / \mathrm{mL}$, TSAT $<25 \%$ and were receiving adequate erythropoietin dosages. Hb response was higher after IV iron treatment than no iron therapy. This study disputed The 2006 Anaemia Clinical Practice Recommendations that there is insufficient evidence of responsiveness to iron when ferritin is $>500 \mathrm{ng} / \mathrm{mL}$.(21)

Majority of patients in our study are from $>61$ years of age group. This may be due to more conservative non-dialytic approach in older people compared to younger patients. Being a tertiary care centre, majority of patients are from CKD stage 5 . Decreased response to IV iron in older age group may be due to age related cytopenias, but least percentage of adequate $\mathrm{Hb}$ response in the age group 41 - 50 years could not be explained, may be because of $80 \%$ of 41 - 50 years group were from CKD stage 5. In our study, females fared slightly better than their male counterparts. There are no statistically significant age, sex and CKD stage wise $\mathrm{Hb}$ responses.

In our study, mean serum ferritin increased from 211 $\mathrm{ng} / \mathrm{dL}$ to $236.6 \mathrm{~g} / \mathrm{dL}$ and TSAT from $21.3 \%$ to $25.9 \%$. In a similar study by Gabriel Mircescu,(15) serum ferritin increased from $98 \mathrm{ng} / \mathrm{mL}$ to $156 \mathrm{ng} / \mathrm{mL}, 3$ months after $600 \mathrm{mg}$ IV iron sucrose and $442.5 \mathrm{ng} / \mathrm{mL} 1$ year after $2400 \mathrm{mg}$ IV iron sucrose. TSAT increased from $21.6 \%$ to $24.9 \%$ (3 months) and $33.6 \%$ ( 1 year).

There are statistically significant serum ferritin and TSAT responses. There are no correlation between $\mathrm{Hb}$ response and serum ferritin and TSAT responses.
When TSAT is $<20 \%$, there is equal $\mathrm{Hb}$ response to IV iron therapy between serum ferritin levels of $<500 \mathrm{ng} / \mathrm{mL}$ and $>500 \mathrm{ng} / \mathrm{mL}$ in CKD patients with anaemia. When TSAT is $20-30 \%$, there is moderate $\mathrm{Hb}$ response if serum ferritin is $<500 \mathrm{ng} / \mathrm{mL}$ and no $\mathrm{Hb}$ response if serum ferritin is $>500$ $\mathrm{ng} / \mathrm{mL}$.

\section{Limitations}

Small sample size, absence of control group and follow-up, $\mathrm{Hb}$ variability and no assessment of inflammatory markers like CRP are some of the limiting factors of the study.

\section{CONCLUSION}

TSAT levels less than $20 \%$ is a better predictor of iron deficiency in non-dialytic CKD patients with anaemia. Further, RCTs are needed in this regard.

\section{REFERENCES}

[1] European best practice guidelines for the management of anaemia in patients with chronic renal failure. Nephrol Dial Transplant 1999;14 Suppl 5:1-50.

[2] Sathyan S, George S, Vijayan P. Prevalence of anemia and cardiovascular disease in chronic kidney disease patients: a single tertiary care centre study. International Journal of Advances in Medicine 2017;4(1):247-51.

[3] Valderrabano F, Horl WH, Macdougall IC et al. Predialysis survey on anaemia management. Nephrol Dial Transplant 2003;18(1):89-100.

[4] Gouva C, Nikolopoulos P, Ioannidis JP, et al. Treating anemia early in renal failure patients slows the decline of renal function: a randomized controlled trial. Kidney Int 2004;66(2):753-60.

[5] Astor BC, Coresh J, Heiss G, et al. Kidney function and anemia as risk factors for coronary heart disease and mortality: the Atherosclerosis Risk in Communities (ARIC) Study. Am Heart J 2006;151(2):492-500.

[6] Babbitt JL, Lin HY. Mechanisms of anemia in CKD. J Am Soc Nephrol 2012;23(10):1631-4.

[7] KDIGO clinical practice guideline for anemia in chronic kidney disease. Kidney International Supplements 2012;2(4).

[8] Macginley R, Walker R, Irving M. KHA-CARI Guideline: use of iron in chronic kidney disease patients. Nephrology (Carlton) 2013;18(12):747-9.

[9] Nagaraju SP, Chon A, Akbari A, et al. Heme iron polypeptide for the treatment of iron deficiency anemia in non-dialysis chronic kidney disease patients: a randomized controlled trial. BMC Nephrology 2013;14:64.

[10] Gaweda AE, Bhat P, Maglinte GA, et al. TSAT is a better predictor than ferritin of haemoglobin response to Epoetin alfa in US dialysis patients. Hemodial Int 2014;18(1):38-46.

[11] Kovesdy CP, Estrada W, Ahmadzadeh S, et al Association of markers of iron stores with outcomes in patients with nondialysis-dependent chronic kidney disease. Clin J Am Soc Nephrol 2009;4(2):435-41.

[12] Fishbane S, Pollack S, Feldman HI, et al. Iron Indices in chronic kidney disease in the National Health and 
Nutritional Examination Survey 1988-2004. Clin J Am Soc Nephrol 2009;4(1):57-61.

[13] Post JB, Wilkes BM, Michelis MF. Iron deficiency in patients with chronic kidney disease: potential role for intravenous iron therapy independent of erythropoietin. Int Urol Nephrol 2006;38(3-4):719-23.

[14] Vikrant S, Parashar A. The safety and efficacy of high dose ferric carboxymaltose in patients with chronic kidney disease: a single centre study. Indian J Nephrol 2015;25(4):213-21.

[15] Agarwal R, Rizkala AR, Bastani B, et al. A randomized controlled trial of oral versus intravenous iron in chronic kidney disease. Am J Nephrol 2006;26(5):44554 .

[16] Qunibi WY, Martinez C, Smith M, et al. A randomized controlled trial comparing intravenous ferric carboxymaltose with oral iron for treatment of iron deficiency anaemia of non-dialysis dependent chronic kidney disease patients. Nephrol Dial Transplant 2011;26(5):1599-607.

[17] Spinowitz BS, Kausz AT, Baptista J, et al. Ferumoxytol for treating iron deficiency anemia in CKD. J Am Soc Nephrol 2008;19(8):1599-605.
[18] Van Wyck DB, Roppolo M, Martinez CO, et al. A randomized, controlled trial comparing IV iron sucrose to oral iron in anemic patients with nondialysis-dependent CKD. Kidney Int 2005;68(6):2846-56.

[19] Gotloib L, Silverberg D, Fudin R, et al. Iron deficiency is a common cause of anemia in chronic kidney disease and can often be corrected with intravenous iron. J Nephrol 2006;19(2):161-7.

[20] Mircescu G, Gârneata L, Capusa C, et al. Intravenous iron supplementation for the treatment of anaemia in pre-dialyzed chronic renal failure patients. Nephrol Dial Transplant 2006;21(1):120-4.

[21] Coyne DW, Kapoian T, Suki W, et al. Ferric gluconate is highly efficacious in anemic hemodialysis patients with high serum ferritin and low transferrin saturation: results of the Dialysis Patients' Response to IV Iron with Elevated Ferritin (DRIVE) Study. J Am Soc Nephrol 2007;18(3):975-84. 